\title{
In vitro Anthelmintic Activity of Coffee Husk Extract Fermented with Pleurotus ostreatus for Ascaridia galli
}

\author{
Irma Badarina*, Heri Dwi Putranto and Endang Sulistyowati \\ Departement of Animal Science, Agricultural Faculty, Bengkulu University, \\ WR Supratman Street, Kandang Limun, Bengkulu, Indonesia \\ *Corresponding author email: ibadarina@yahoo.com
}

\begin{abstract}
The aim of this research was to evaluate the anthelmintic activity the extracts of coffee husk fermented with Pleurotus ostreatus against Ascaridia galli. In vitro study of anthelmintic activity was conducted by counting the number of paralyzed worm body of Ascaridia galli during 24 hours in petri dish containing different levels of ethanol and water extract of fermented coffee husk 1, 2, 3 and $4 \%$ (w/v) respectively and compared to piperazine $0.5 \%(\mathrm{w} / \mathrm{v})$ and $\mathrm{NaCl} 0.9 \%$. The powdered samples of fermented coffee husk were macerated in the $30 \%$ ethanol solution with the ratio samples to solution $=1: 3$. In water extract, samples to solution ratio was 1:7. A Completely Randomized Design was used in this study with ten treatments with four replicates each incorporating five worms. The data were analyzed for its variances with anova. The extract of fermented coffee husk contained phytochemical compounds which may be responsible for anthelmintic activity such as saponin, flavonoid, tannin dan phenolic. The worms were $100 \%$ paralized on piperazine group and none on $\mathrm{NaCl} 0.9 \%$. The anthelmintic activity of ethanol extract was better than water extract. Up to $4 \%$ level of water extract, there was no significant effect to mortality of A. galli. The ethanolic extract of fermented coffee husk showed the mortality started at concentration $2 \%$. The mortality increased significantly at $3 \%$ level of ethanolic extract. The highest mortality was at concentration $4 \%$ butno significant effect with $3 \%$ level. The ethanolic extract have the potency as anthelmintic for $A$. galli.
\end{abstract}

Key words: fermented, coffee husk, extract, anthelmintic, Ascaridia galli

Abstrak. Penelitian ini bertujuan untuk mengevaluasi aktivitas anthelmintik in vitro ekstrak kulit buah kopi yang difermentasi dengan Pleurotus ostreatus terhadap Ascaridia galli. Studi in vitro aktivitas anthelmintik dilakukan dengan menghitung jumlah cacing yang paralisis setelah 24 jam di dalam cawan petri yang masing-masing berisi beberapa tingkat konsentrasi ekstrak etanol dan ekstrak air kulit kopi fermentasi yaitu 1, 2, 3 dan 4\% (w/v) dan dibandingkan dengan piperazine 0,5\% (w/v) dan $\mathrm{NaCl} 0,9 \%$. Ekstraksi dilakukan dengan merendam kulit kopi fermentasi dalam larutan etanol 30\% dengan perbandingan 1:3 dan ekstraksi menggunakan air dengan perbandingan 1:7. Rancangan percobaan menggunakan Rancangan Acak Lengkap dengan sepuluh perlakuan. Terdapat empat ulangan setiap perlakuan dengan lima ekor cacing setiap ulangan. Data dianalisis keragamannya dengan anova. Ekstrak dari kulit buah kopi fermentasi memiliki senyawa fitokimia yang kemungkinan bertanggung jawab sebagai anthelmintika seperti saponin, glikosida, flavonoid, tannin dan phenolik. Cacing A. galli 100\% mati pada kelompok kontrol piperazin $0,5 \%$, tetapi tidak ada cacing yang mati pada perlakuan $\mathrm{NaCl} 0,9 \%$. Aktivitas anthelmintik ekstrak etanol lebih baik daripada ekstrak air. Sampai pada konsentrasi 4\%, tidak terdapat pengaruh yang nyata terhadap kematian cacing pada ekstrak air. Ekstrak etanol menunjukkan kematian $A$. galli mulai konsentrasi $2 \%$. Pada konsentrasi ekstrak etanol 3\% menunjukkan kenaikan tingkat kematian yang signikan. Kematian tertinggi pada konsentrasi ekstrak etanol $4 \%$ walaupun tidak berbeda nyata dengan konsentrasi ekstrak etanol 3\%. Ekstrak etanol memiliki potensi sebagai anthelmintik terhadap $A$. galli.

Kata kunci: fermentasi, kopi buah kulit, ekstrak, anthelmintik, Ascaridia galli

\section{Introduction}

Gastro intestinal parasites (GIP) have direct effects on and remain one of the main problems to productivity of the livestock. Ascaridia galli, an intestinal nematode that affects production of hens and other domestic wild birds, causes economic losses in avian production (Marcos-axtutegi et al., 2009). The common control mode of GIP based on the use of anthelmintics is now strongly questioned because of the increasing development of resistance and residual effect 
to animal product (Wolstenholme et al., 2004; Sissouma et al., 2011). Thus, alternative GIP control strategies are necessary.

Alternative environment friendly sustainable strategies are required, which could reduce the exclusive reliance on anthelmintic treatment. Mushrooms have been used from ancient times to cure diseases of man and animals and as food supplement for medicinal properties. One of the mushrooms is Pleurotus ostreatus ( $P$. ostreatus) containing a number of active compounds that help as health-enhancers, potential against diseases and as biological response modifiers (Wong et al., 2011; Patel et al., 2012). Ganeshpurkar et al. (2012) reported that there was anthelmintic potential of Pleurotus florida to Ascaridia galli. Haque et al. (2105) concluded that the extract of Pleurotushighking have potent anthelmintic activity when compared with the conventionally used drug. The content of bioactive compounds from mushroom may be responsible for anthelmintic action. $P$. ostreatus was the same genus with Pleurotus florida, so it is expected to have anthelmintic activity.

In several studies, the use of plant as an alternative gastro intestinal control strategies may be attributed to the presence of active ingredients responsible for the activity. In few cases, the phytochemical examination of concerned plants has also been made and the active principle has been isolated and tested for anthelmintic activity. In all these studies, comparisons of plants' efficacy has been made with one or other synthetic anthelmintic drug such as albendazole, piperazine citrate, etc. (Ekeanyanwu and Etienajirhevwe, 2012)

Pleurotus ostreatus can be cultivated on a wide range of lignoselulosic substrates because produce ligninolytic extracellular enzymes, such as laccases, lignin peroxidases and $\mathrm{Mn}$ peroxidases (Widiastuti and Panji, 2008; Alemawor, 2009).
The ability of $P$. ostreatus to degrade a wide variety of lignoselulosic substrates plays an important role in managing organic wastes with problematic disposal. Coffee husk is one of the principal by products produced during the operation of coffee cherry to get coffee grain by sun drying (Murthy and Mannomani, 2008; Fan and Soccol, 2005). Indonesia is one of coffee-producing countries but the coffee husk is barely utilized.

Present study intends to perform the preliminary phytochemical screening of ethanol and water extract of coffee husk fermented by $P$. ostreatus and to evaluate the anthelmintic activity to A.galli in vitro examination.

\section{Materials and Methods}

\section{Coffee Husk Cultivation with Pleurotus ostreatus}

Coffee husks were sun dried until its moisture content ranged $10 \%-15 \%$. The cultivation method and the composition of solid substrate were conducted according to Herliyana et al. (2008) with slight modification. The substrate consisted of $82.5 \%$ coffee husks, $15 \%$ rice bran, $1.5 \%$ gips and $1.0 \% \mathrm{CaCO}_{3}$. The clean water was added into the substrate as much as $65-70 \%(\mathrm{v} / \mathrm{w})$. All the components were composted for $24 \mathrm{~h}$, weighed $400 \mathrm{~g}$ to store into polypropylene bags. The bag logs were sterilized on $121^{\circ} \mathrm{C}$ for $30 \mathrm{~min}$. After cooling, each bag was inoculated aseptically with $P$. ostreatus grain spawn and incubated in an incubating room at $23-24^{\circ} \mathrm{C}$ and approximately $80 \%$ relative humidity. Each spawned bag was closed with a small sterile cotton plug inserted in the middle of its opening. All bags were placed in incubating room and after $60 \mathrm{~d}$ the substrates were fully colonized and the primordial started to appear. The fully colonized substrates were sun dried and ready to use. 
Preparation, Extraction and Phytochemical Properties of the Extracts

The samples were dried and pulverized into fine powder. The water and ethanol extracts were prepared using the maceration. The powdered samples were macerated in the $30 \%$ ethanol solution with the ratio samples to solution $=1: 3$. In aqueous, samples to solution (distilled water) ratio was 1:7. The suspensions were stirred and precipitated overnight then be refined. The supernatants were retained and the residue was discarded. The supernatants were dried in vacuum rotavapor at $45^{\circ} \mathrm{C}$ to obtain the concentrate extracts. The obtained extracts were examined for the presence of alkaloids, flavonoids, phenol hidroquinon, steroids, triterpenoids, tannin, and saponin as described by Harborne (1989).

\section{In vitro Anthelmintic Assay}

Ascaridiagalli were collected from freshly slaughtered native chicken intestines in the local abattoir. The worms were washed repeatedly using $\mathrm{NaCl} 0,9 \%$. As much as 20 $\mathrm{ml} \mathrm{NaCl} 0,9 \%$ were placed into petri dish plate and the extract of fermented coffee husk were added into the petri dish with the final concentration $1,2,3$ and $4 \%(w / v)$. The piperazin $0.5 \%(\mathrm{w} / \mathrm{v})$ and $\mathrm{NaCl} 0.9 \%$ were used as positive and negative control.

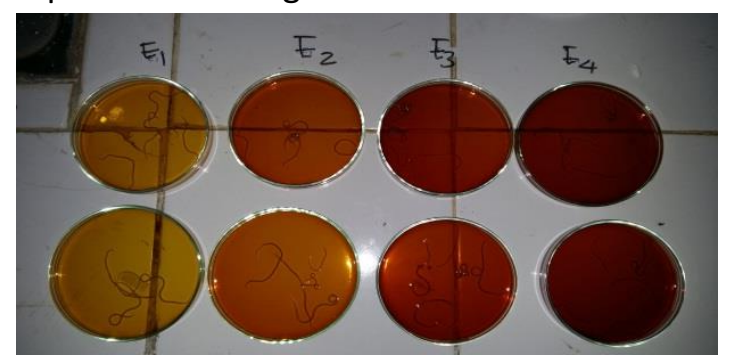

Figure 1. In vitro anthelmintic assay

Five adult worms without any sexing, with the same weight and body length were put into the plates. There were four replicates for each extract concentration and control. The plates were further incubated for $24 \mathrm{~h}$ in temperature room. Paralysis was said to occur when the worms were not able to move even in lukewarm normal saline.The research was arranged in Completely Randomized Design with ten treatments and four replications. The data were analyzed for statistical significance using anova. For detailed test used Duncan Range Test. Difference at $\mathrm{P}<0.05$ was considered as significant.

\section{Results and Discussion}

\section{Phytochemical Screening}

The results of phytochemical evaluation of secondary phytoconstituents are listed in Table 1. The phytochemical evaluation confirmed the presence of saponin, glycosides, flavonoids, tannins and phenolic compounds.

Ethanolic extractionyield of fermented coffee husk was $2.105 \%$ and water extract was $5.75 \%$. The ethanol extract contained alkaloids, tannins, saponins, flavonoids and triterpenes. On water extract contained saponin and flavonoid. The solubility of secondary substances in ethanol solvent were much more than water. Gamse (2002) stated that the important considerations to select solvent were the selectivity, the characteristic of the solvent, the abililty to extract, no harmful, easy to evaporate and not expensive.

Table 1. Phytochemical properties of the ethanolic and aqueous extracts of coffee husk fermented by $P$. ostreatus

\begin{tabular}{lcc}
\hline Phytochemical properties & Ethanol & Water \\
\hline Alkaloid & +++ & - \\
Flavonoid & ++ & ++ \\
Phenolhidroquinon & + & - \\
Steroid & - & - \\
Triterpenoid & + & - \\
Tanin & ++ & - \\
Saponin & +++ & ++ \\
\hline - No concentration, + Present, & +++ & present in high \\
concentration &
\end{tabular}

These phytochemical principles could be responsible for the observed pharmacological activity. Osemwegie et al. (2012) reported 
that the classes of phytochemicals e.g. alkaloids, saponins, tannins, steroids and triterpenes recorded in this study are capable of depressing gastrointestinal parasites of pigeon supplemented with Ganodermalucidum.

Coffee husk subtrate fermented by $P$. ostreatus showed a great potential in phytochemical contents. Coffee husks were rich in phenolic compound (tannin, saponin, flavonoid) and alkaloid (caffeine) (Esquivel and Jimenez, 2012).

\section{In vitro Anthelmintic Assay}

The anthelmintic activity of ethanol extract was better than that of water extract (Table 2). The difference of anthelmintic activity between ethanol and water extract was regarded to the their phytochemical profile (Table 1).

The ethanol extract of fermented coffee husk on the concentration $3 \%$ showed a significant increase in the mortality. The use of $4 \%$ was not significantly different from the $3 \%$. Adult mortality assay of $A$. galli soaked in ethanol extract solution on the concentration of $1,2,3$ and $4 \%$ were 0 worm $(0.0 \%), 3$ worms (15.0\%), 9 worms (45.0\%) and 12 worms $(60.0 \%)$, respectively (Table 2 ). It indicated that the higher concentration of the ethanol extract, the higher anthelmintic activity.

The mortality of $A$. galli soaked in water extract solution across the concentrations was not significantly different. Concentration of 1 , 2, 3 and $4 \%$ had 4 (20.0\%), 4 (20.0\%), 5 (25.0\%) and 5 worms (25.0\%), respectively.

Piperazin had the strongest anthelmintic activity, while on $\mathrm{NaCl} 0.9 \%$ solution no mortality of worms showed. $\mathrm{NaCl} 0.9 \%$ named physiological $\mathrm{NaCl}$ was the solution the same with the condition of worm body solution.

The mechanism of fermented coffee husk as anthelmintic may be related to the presence of bioactive molecules. Pathak et al. (2013) reported that the leaf from forage containing condesed tannin could be used as anthelmintic. Gupta et al. (2012) reported that Pleurotus florida revealed the presence of different secondary metabolites contain carbohydrates, alkaloids, glycosides, flavonoids, tannins, saponins and steroids.

Another study reported the anthelmintic activity of Jatropha curcass Linn (Suharti et al., 2010), a plant rich in phytochemicals that may contribute to the anthelmintic activity. The possible anthelmintic effect of tannins is that they can bind to free proteins in the gastrointestinal tract of host animal or glycoprotein on the cuticle of the parasite, and may cause death (Min and Hart, 2003).

Table 2. The in vitro anthelmintic activity assays of ethanolic and aqueous extract of coffee husk fermented with P.ostreatus to the paralysis of A.galli

\begin{tabular}{lcc}
\hline \multicolumn{1}{c}{ Treatment } & \multicolumn{2}{c}{ The sum of paralysis worms } \\
\cline { 2 - 3 } & numbers & $(\%)$ \\
\hline Without fermented coffee extract (NaCl 0,9\%) & $0(20)$ & 0,0 \\
Piperazin (0,5\%) & $20(20)$ & 100,0 \\
Ethanolic Fermented coffee husk extract 1\% & $0(20)$ & $0.0^{\mathrm{a}}$ \\
Ethanolic fermented coffee husk extract 2\% & $3(20)$ & $15.0^{\mathrm{a}}$ \\
Ethanolic fermented coffee husk extract 3\% & $9(20)$ & $45.0^{\mathrm{b}}$ \\
Ethanolic fermented coffee husk extract 4\% & $12(20)$ & $60.0^{\mathrm{b}}$ \\
Aqueous fermented coffee husk extract 1\% & $4(20)$ & $20.0^{\mathrm{a}}$ \\
Aqueous fermented coffee husk extract 2\% & $4(20)$ & $20.0^{\mathrm{a}}$ \\
Aqueous fermented coffee husk extract 3\% & $5(20)$ & $25.0^{\mathrm{a}}$ \\
Aqueous fermented coffee husk extract 4\% & $5(20)$ & $25.0^{\mathrm{a}}$ \\
\hline Mean values within different superscripts shows significant difference (P<0.05) & &
\end{tabular}


The main possible actions of saponins are changes in membrane permeability and pore formation, similar with two conventional anthelmintic drugs such as praziquantel and toltrazuril. The anthelmintic drug affects the permeability of the cell membrane of worm, causing vacuolisation and disintegration of the teguments (Wang, 2010). Alkaloids may have acted on the central nervous system of the earth worms causing paralysis (Roy, 2010). The effect could be due to presence of the steroidal alkaloids oligosaccharides which have been reported to suppress the transfer of sucrose from the stomach to the small intestine which could diminish the availability of glucose to helminths together with its antioxidant effect which is capable of reducing the nitrate generation.

\section{Conclusion}

The ethanol extract of fermented coffee husk can be used as natural anthelmintic. The concentration of ethanolic extract of fermented coffee husk as much as $4 \%$ were effective as anthelmintic in vitro.

\section{Acknowledgement}

Sincerest gratitude goes to te Higher Education Directorate of Education Ministry through National strategic grant with research agreement number 344/ UN30.15/LT/2015 dated March $10^{\text {th }} 2016$ batch 2.

\section{References}

Alemawor F, VP Dzogbefia, EOK Oddoye and JH Oldham. 2009. Effect of Pleurotus ostreatus fermentation on cocoa pod husk composition: influence of fermentation period and $\mathrm{Mn}^{++}$ supplementation on the fermentation process. African J. of Biotech. 8(9):1950-1958.

Ekeanyanwu RC and OF Etienajirhevwe. 2012. In vitro anthelmintic potentials of Xylopiaaethiopica and Monodoramyristica from Nigeria. African J. of Biochemistry Res. 6(9):115120.
Esquivel $P$ and VM Jimenez. 2012. Functional properties of coffee and coffee byproducts. Food Res. Int. 46:488-495.

Fan L and CR Soccol. 2005. Coffee residues. http://www.fungifun.org/mushworld/shiitakemush-room-cultivation/mushroom-growershandbooks2-mushworld-com-chapter04-02p.92.pdf. Accessed: 26 Maret 2010.

Ganeshpurkar A, SS Bhadoriya, P Pardhi and G Rai. 2012. Investigation of anthelmintic potential of oyster mushroom Pleurotus florida. Indian J. Pharmacol. 44(4):539-540.

Gupta N. 2014. Preliminary phytochemical screening of different extracts of Pleurotusflorida. Columbia J. of Pharmaceutical Sciences. Vol 1: April-June, Pages:23-26. http://www.cjps.in/upload/5_CJPS_1_1_2014.p df. Accessed: 8 Oktober 2016

Haque MA, AK Sarker, RK Paul, SS Khan and MAUI Islam. 2015. Screening for antiparasitic activity of crude extracts of pleurotushighking, a Bangladeshi Edible Mushroom. Bangladesh Pharmaceutical J. 18(1):38-41.

Harborne JB. 1989. General procedures and measurement of total phenolics. In J. B.Harborne (Ed.). Methods in plant biochemistry: Vol. 1 Plant Phenolics (pp. 1-28). Academic Press. London.

Herliyana EN, D Nandika, Achmad, LI Sudirman and $A B$ Witarto. 2008. Biodegradation of sengonwood sawdust substrate by Pleurotus group fungi from Bogor. J. of Trop. Wood Sci. and Technol. 6:75-84.

Marcos-Atxuteg Ci, B Gandolfi, TT Arangüena, R Sepúlveda, M Arévalo and F Simón. 2009. Antibody and inflammatory responses in laying hens with experimental primary infections of Ascaridia galli. Veterinary Parasitology. 161(1-2):69-75.

Min BR and SP Hart. 2003. Tannins for suppression of internal parasites. J. Anim. Sci. 81(E. Suppl. 2):E102-E109.

Mussatto SI, Machado EMS, Martins S, Teixeira JA. 2011. Production, composition, and application of coffee and its industrial residues. Food Bioprocess Technol. 4:661-672.

Patel Y, R Naraian and VK Singh. 2012. Medicinal properties of Pleurotus species (Oyster mushroom): A review. World J. of Fungal and Plant Biol. 3(1):01-12.

Pathak AK, N Dutta, PS Banerjee, AK Pattanaik and K Sharma. 2013. Influence of dietary supplementation of condensed tannins through leaf meal mixture on intake, nutrient utilization and performance of Haemonchus contortus infected sheep. Asian Australia J. Anim. Sci. 26(10):1446-1458. 
Roy H. 2010. Preliminary phytochemical investigation and anthelmintic activity of Acanthospermum hispidum D.C. J. Pharm. Sci. Technol. 2(5):217-221.

Sissouma S, M Ouattara, MW Koné, HE Menan, A Adjou and L Ouattara. 2011. Synthesis and in vitro nematicidal activity of new chalcones vectorised byimidazopyridine. Research paper. African J. of Pharmacy and Pharmacology. 5(18):2086-2093.

Suharti S, KG Wiryawan, R Tiuria, Y Ridwan, S Fitriana and N Sumarni. 2010. Effectiveness of Jatropha curcass Linn leaves as an anthelmintic for Ascaridia galli and its effect on native chicken performance. Media Peternakan. 33(2):108-114
Wang GX. 2010. In vivo anthelmintic activity of five alkaloids from Macleaya microcarpa (maxim) fedde against Dactylogyrus intermedius in Carassius auratus. Vet. Parasitol. 171: 305-313.

Widiastuti $\mathrm{H}$ and T Panji. 2008. Activity pattern of ligninolytic enzyme of Pleurotus ostreatus in sludge waste of paper factory. Menara Perkebunan. 76(1):47-60.

Wolstenholme AJ, I Fairweather, R Prichard, G von Samson- Himmelstjerna and NC Sangster. 2004. Drug resistance in veterinary helminthes. Trends in Parasitology. 20:469-476.

Wong KH, CKM Lai and PCK Cheung. 2011. Immunomodulatory activities of mushroom sclerotial polysaccharides. Food Hydrocolloids. 25:150-158. 